\title{
RANCANG BANGUN SISTEM KENDALI LAJU ALIR FLUIDA PADA DUAL RESERVOIR BERBASIS ARDUINO-LABVIEW Siti Rokhmanila', ${ }^{1}$ andiansyah ${ }^{2}$
}

\author{
1,2 Jurusan Teknik Elektro FT UNPAM \\ Jln. Puspiptek Raya No 11 Buaran, Tangerang Selatan 15310 INDONESIA \\ Inilacherry@gmail.com
}

\begin{abstract}
ABSTRAK
Sistem kendali ketinggian level air pada sebuah tangki banyak digunakan pada industri. Perancangan dan pembuatan simulasi sistem pengatur ketinggian air pada dua tangki telah dilakukan menggunakan mikrokontroler arduino uno R3, relay, pompa air, sensor aliran YFS201dan program LABVIEW. Sistem ini menggunakan sensor laju alir YF-S201untuk mengatur debit air yang masuk ke dalam tangki dan sensor ultra sonik untuk mengukur ketinggian level air. Karena sistem ini dibuat sebagai alat simulasi, maka data kecepatan laju alir dan ketinggian level air dapat dipantau menggunakan komputer. Pengambilan data dilakukan dengan membaca sensor-sensor oleh mikrokontroler yang kemudian dikirim secara serial ke komputer menggunakan program LabVIEW. Komunikasi antara mikrokontroler dan komputer menggunakan mode firmata yang sudah terintegrasi dengan LabVIEW, sehingga pembuatan program hanya dilakukan pada sisi komputer saja. Sedangkan pada sisi mikrokontroler hanya perlu menambahkan sub program firmata yang sudah dibuat oleh arduino. Perhitungan kecepatan laju alir, debit, ketinggian level air dan penampilan data serta kontrol ketinggian level air dilakukan pada program LabVIEW. Sensor water flow YF-S201 dapat digunakan untuk mengukur kecepatan laju alir air (fluida) pada drain system dan operation reservoir terimplementasikan dengan menunjukkan kestabilan pembacaan dengan rata-rata tegangan $(2,96 \mathrm{~V})$ dan flow rate $(13,40 \mathrm{~L} / \mathrm{det})$ pada drain system. Rata-rata tegangan $(2,80 \mathrm{~V})$ dan flow rate $(12,70 \mathrm{~L} / \mathrm{det})$ pada operation reservoir 1 dan rata-rata tegangan $(2,01 \mathrm{~V})$ dan flow rate $(13,66 \mathrm{~L} / \mathrm{det})$ pada operation reservoir 2.
\end{abstract}

Kata kunci : Level air, firmata, arduino, LabVIEW, sensor aliran YF-S201, pompa air, sensor ultrasonik

\begin{abstract}
Water level control system in a tank is widely used in industry. Design and development of regulating water levels simulation system in the two tanks have been carried out using a microcontroller arduino uno R3, relay, water pump and fluida sensor YF02-01. The system uses flow rate sensors to regulate the water that flow into the tank and ultra sonic sensor to measure the height of the water level. Due to the system is created as a simulation tool, the data speed of the flow rate and the height of the water level can be monitored using a computer. The data is read from the sensor that controlled by microcontroller. The data then sent serially to the computer using the LabVIEW program. The communication between the microcontroller and computer use firmata mode which is integrated with LabVIEW. Therefore, the designing of the program is only assembled on the computer side. On the other hand, on the microcontroller side, it only needs to add the firmata sub program that has been created by arduino. The calculation of the flow rate, discharge, water level, appearance of data and water level control are performed in LabVIEW program. Water flow sensor YF-S201 used to water flow instrument in drain system and operation reservoir implementation with shows stability reading in voltage average $(2,96 \mathrm{~V})$ dan flow rate $(13,40 \mathrm{~L} / \mathrm{sec})$ in drain drain systems. Voltage average $(2,80 \mathrm{~V})$ and flow rate $(12,70 \mathrm{~L} / \mathrm{sec})$ in reservoir operation 1 and voltage average $(2,01 \mathrm{~V})$ and flow rate $(13,66 \mathrm{~L} / \mathrm{sec})$ in reservoir opration 2.
\end{abstract}


Journal Of Electrical Power, Instrumentation and Control (EPIC)

Teknik Elektro - Universitas Pamulang

Keywords : Level air, firmata, arduino, LabVIEW, Fluida sensor YF-S201, water pump, ultrasonic sensor 


\section{PENDAHULUAN}

$\mathrm{S}$ istem akuisisi data merupakan salah satu bagian yang penting dalam dunia industri saat ini karena dengan akuisisi data akan diperoleh berbagai masukan data untuk mendapatkan informasi dan menentukan sistem kendali proses serta sebagai jaminan dari kualitas proses itu sendiri. Sistem akuisisi data dilakukan terhadap berbagai macam parameter, salah satu parameter yang banyak digunakan dalam dunia industri adalah sistem akuisisi data air (fluida). Kemampuan dalam pengendalian proses diperlukan bagi para mahasiswa teknik (calon teknisi profesional) sebagai modal menghadapi dunia industri nyata termasuk industri dalam bidang perairan. Dengan parameter air (fluida) sebagai dasar pengendalian proses, sehingga diperoleh berbagai informasi mengenai aliran yang dapat difungsikan sebagai masukan dalam pengendalian proses debit air (fluida) pada sistem yang dibangun. Sistem yang dibangun dapat pula diaplikasikan pada dunia industri seperti sistem pelapisan air kimia (coating) pada permukaan kaca, atau air pendinginan (water cooling system) pada proses pembakaran material pada industri kaca atau metal. Oleh Karena latar be;akang tersebut, penulis melakukan penelitan yang membahas laju aliran fluida.

Didalam penelitian ini akan dirumuskan beberapa masalah yaitu bagaimana menerapkan sensor ultrasonic HC-SRF04 untuk mengukur level ketinggian cairan dan penerapan sensor laju aliran YF-s201 untuk mengukur kecepatan laju aliran dengan menggunakan arduino dan LABVIEW. Adapun parameter yang dipergunakan di dalam penelitian ini adalah kecepatan laju alir, waktu dan tegangan. Tujuan dari penelitian ini adalah membuat miniatur dan sistem pengendali laju aliran cairan pada dual reservoir, berupa modul praktikum dalam Laboratorium Praktikum Jurusan Tekhnik Elektro Universitas Pamulang dan menampilkan pengendaliannya serta sistem akuisisi data dari perangkat lunak LabVIEW yang berinteraksi dengan Arduino yang difungsikan sebagai interface.

\section{TEORI}

\subsection{Sistem Kendali}

Sistem adalah kombinasi atas beberapa komponen yang bekerja bersama-sama untuk melakukan suatu pekerjaan tertentu.

Pada umumnya sistem kendali dibagi menjadi dua jenis yaitu:

1. Sistem Kendali Terbuka (Open Loop Control System)

Sistem dimana hasil outputnya tidak mempengaruhi aksi kontrol. Pada sistem ini tidak dilakukan perbandingan antara sinyal output dan input. Performasi dan akurasi dari aksi kontrol sistem ini tergantung dari kalibrasi sistem. Jika terdapat gangguan maka sistem tidak dapat mengantisipasinya sehingga harus dikalibrasi ulang. Sebagai contoh, sistem kontrol yang berbasiskan setting waktu adalah sistem kontrol open loop.

Untuk lebih jelasnya tampilan sistem kendali terbuka (open loop) dapat dilihat pada gambar 1 berikut ini:

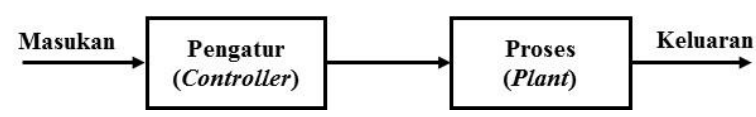

Gambar 1. Sistem Kendali Terbuka (Open Loop Control System).

2. Sistem Kendali Tertutup (Close Loop Control System)

Sistem kendali tertutup merupakan sistem kontrol umpan balik yang menggunakan hubungan antara output dan input yang diinginkan dengan teknik membandingkannya. Hasil perbandingan ini merupakan deviasi yang digunakan sebagai alat kontrol. Actuating error signal yang merupakan perbedaan antara input dan feedback (dapat berupa output itu sendiri atau fungsi dari output seperti turunan atau integralnya), diumpankan ke pengontrol. Pengontrol mengurangi error dan membawa sistem pada keadaan yang diinginkan (output sesuai dengan input 
yang diinginkan). Jadi output mempengaruhi aksi kontrol.

Untuk lebih jelasnya tampilan sistem kendali tertutup (close loop) dapat dilihat pada gambar 2 berikut ini:

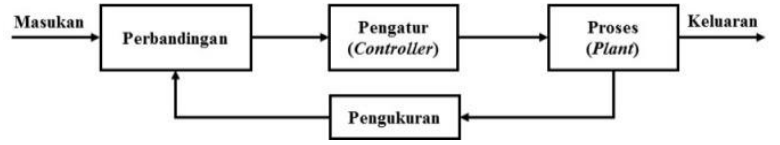

Gambar 2. Sistem Kendali Tertutup (Close Loop Control System).

\subsection{Air (Fluida)}

Air (fluida) adalah suatu zat yang dapat mengalir. Air (fluida) dapat digolongkan ke dalam zat cair dan gas. Zat yang dapat mengalir dan dapat memberikan sedikit hambatan terhadap perubahan bentuk ketika ditekan baik itu dalam bentuk air atau gas, selama bisa mengalir disebut air (fluida). Hampir semua bentuk air dan gas disebut air (fluida), karena zat cair dan gas memiliki sifat fisik yang dapat mengalir dari satu tempat ke tempat yang lain. Pada penelitian ini mempergunakan fluida cair.

Tekanan hidrostatik adalah tekanan pada zat cair yang diam sesuai dengan namanya (hydro: air dan static: diam), atau lebih lengkapnya tekanan hidrostatik didefinisikan sebagai sebagai tekanan yang diberikan oleh air pada kesetimbangan karena pengaruh gaya gravitasi. $\mathrm{Hal}$ ini berarti setiap benda yang berada pada zat cair yang diam, tekanan tergantung dari besarnya gravitasi.

Tekanan merupakan gaya yang bekerja tegak lurus pada suatu bidang dibagi dengan luas bidang tersebut, tidak menjadi masalah bagaimana orientasi permukaan (tegak, mendatar atau miring). Tekanan tidak memiliki arah tertentu hingga tekanan termasuk besaran skalar. Berbeda dengan tekanan, sebuah gaya adalah sebuah vektor, yang berarti memiliki arah tertentu.

Rumus dari tekanan hidrostatis adalah sebagai berikut:

$$
\begin{aligned}
& P=\rho . g . h \\
& \text { Dimana : } \\
& P=\text { Tekanan hidrostatis }\left(\mathrm{kg} / \mathrm{m}_{.} \text {detik }^{2}\right) \\
& \rho=\text { Massa jenis zat cair }\left(\mathrm{kg} / \mathrm{m}^{3}\right) \\
& \mathrm{g}=\text { Percepatan gravitasi bumi }(\mathrm{m} / \\
& \text { detik } \left.^{2}\right) \\
& \mathrm{h}=\text { Kedalaman zat cair }(\mathrm{m})
\end{aligned}
$$

Hukum utama hidrostatis menyatakan bahwa semua titik yang berada pada satu bidang datar dalam fluida homogeny, memiliki tekanan total sebanding. Jadi, walaupun bentuk penampang tabung berbeda, besarnya tekanan total di titik A, B, $C$, dan $D$ adalah sebanding.Untuk lebih jelasnya tampilan hukum utama hidrostatis dapat dilihat pada gambar 3. berikut ini:

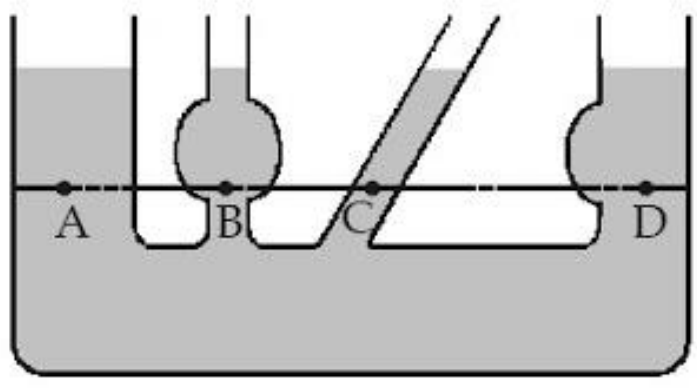

Gambar 3. Hukum Utama Hidrostatis.

Tekanan total di titik $A$ dan titik B bergantung pada masa jenis dan ketinggian fluida di dalam tabung. Secara matematis, persamaannya dapat dituliskan sebagai berikut:

$\mathrm{pA}=\mathrm{pB}$
$\mathrm{h}_{1}=$ Jarak titik $\mathrm{A}$ terhadap permukaan
fluida 1
$\mathrm{h}_{2}=$ Jarak titik $\mathrm{B}$ terhadap permukaan
fluida 2
$\rho_{1}=$ Massa jenis fluida 1
$\rho_{2}=$ Massa jenis fluida 2

Dimana

$$
\begin{gathered}
P_{0}+\rho_{1} g h_{1}=P_{0}+\rho_{2} g h_{2} \\
\rho_{1} g h_{1}=\rho_{2} g h_{2}
\end{gathered}
$$

Berikut ini pada tabel 1 menunjukkanMassa jenis zat:

Tabel 1. Massa Jenis Zat. 


\begin{tabular}{|c|l|c|c|}
\hline No. & \multicolumn{1}{|c|}{ Nama Zat } & Massa Jenis (g/cm3) & Massa Jenis $(\mathbf{k g} / \mathbf{m 3})$ \\
\hline 1 & Air $\left(\right.$ suhu $\left.4^{0} \mathrm{C}\right)$ & 1,00 & 1000 \\
\hline 2 & Alkohol & 0,80 & 800 \\
\hline 3 & Air raksa/mercury & 13,60 & 13600 \\
\hline 4 & Alumunium & 2,70 & 2700 \\
\hline 5 & Besi & 7,90 & 7900 \\
\hline 6 & Emas & 19,30 & 19300 \\
\hline 7 & Es & 0,92 & 920 \\
\hline 8 & Kuningan & 8,40 & 8400 \\
\hline 9 & Perak & 10,50 & 10500 \\
\hline 10 & Platina & 21,45 & 21450 \\
\hline 11 & Seng & 7,14 & 7140 \\
\hline
\end{tabular}

Kapasitas aliran (Q) untuk fluida yang tidak termampatkan (incompressible), yaitu:

$\mathrm{Q}=\mathrm{A}, \mathrm{v}$

Dimana:

$\mathrm{Q}=$ Laju aliran fluida $\left(\mathrm{m}^{3} / \mathrm{s}\right)$

$A=$ Luas penampang aliran fluida $\left(m^{2}\right)$

$\mathrm{v}=$ Kecepatan rata-rata aliran fluida $(\mathrm{m} / \mathrm{s})$

Laju aliran berat fluida (W), yaitu:

$$
\mathrm{W}=y, \mathrm{~A}, \mathrm{v}
$$

Dimana:

$\mathrm{W}=$ Laju aliran berat fluida (Ns)

$y=$ Berat jenis fluida $\left(\mathrm{N} / \mathrm{m}^{3}\right)$

Laju aliran fluida Massa (M), yaitu:

$M=\rho, A, v$

Dimana:

$M=$ Laju aliran massa fluida $(\mathrm{kg} / \mathrm{s})$

$\mathrm{P}=$ Berat jenis fluida $\left(\mathrm{kg} / \mathrm{m}^{3}\right)$.

\subsection{Pompa Air}

[Iwan Setiawan, 2009]

Pompa air adalah satu tipe pompa yang memanfaatkan energi kecepatan yang kemudian diubah menjadi energi tekanan sehingga dapat menggerakkan air (fluida) dari lokasi sumber menuju lokasi target. Untuk lebih jelasnya tampilan pompa air dapat dilihat pada gambar 4 berikut ini:

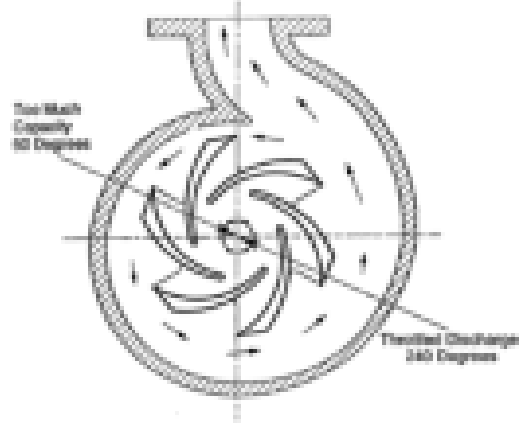

Gambar 4. Pompa Air.

\subsection{Relay}

Relay merupakan salah satu perangkat elektronik yang sering digunakan dalam membuat suatu perangkat keras. Dalam dunia elektronika, relay dikenal sebagai komponen yang dapat mengimplementasikan logika switching. Secara sederhana relay elektromekanis ini didefinisikan sebagai berikut:

1. Alat yang menggunakan Gaya elektromagnetik untuk menutup atau membuka kontak saklar.

2. Saklar yang digerakkan secara mekanis oleh daya/energi listik.

Untuk lebih jelasnya tampilan relay dapat dilihat pada gambar 5 berikut ini:

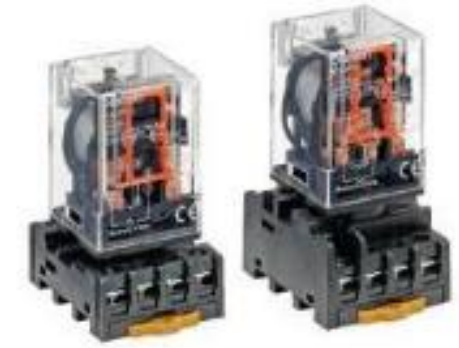

Gambar 5. Relay.

\subsection{Sensor Ultrasonik HC-SR04}

Sensor ultrasonic HC-SR04 menggunakan sonar untuk menentukan jarak ke suatu objek, dapat mendeteksi berbagai jenis benda noncontact dengan baik, akurasi tinggi dan pembacaan stabil yang mudah untuk menggunakannya. Dilengkapi dengan modul pengiriman (transmitter) dan modul penerima (receiver) ultrasonik.

Berikut ini fitur-fitur dari sensor ultrasonik HC-SR04:

1. Power supply: +5 V DC

2. Quiescent Current: $<2 \mathrm{~mA}$ 
3. Working Current: $15 \mathrm{~mA}$

4. Effectual Angle: $<15^{\circ}$

5. Ranging Distance: $2 \mathrm{~cm}-400 \mathrm{~cm} / 1 "$ - 13"

6. Resolution: $0,3 \mathrm{~cm}$

7. Measuring Angle: 30 degree

8. Trigger Input Pulse width: 10 uS

9. Dimension: $45 \mathrm{~mm} \times 20 \mathrm{~mm} \times 15 \mathrm{~mm}$

Adapun layout dan jangkauan sensor ultrasonik HC-SR04 dapat terlihat pada gambar 6 dan 7 serta spesifikasi dan batasan sensor ultrasonik HC- SR04 dapat dilihat pada tabel 2 berikut ini:

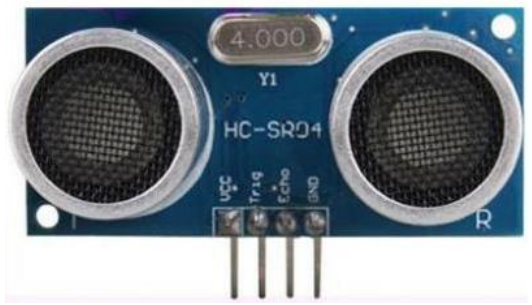

Gambar 6. Layout Sensor Ultrasonik HC-SR04
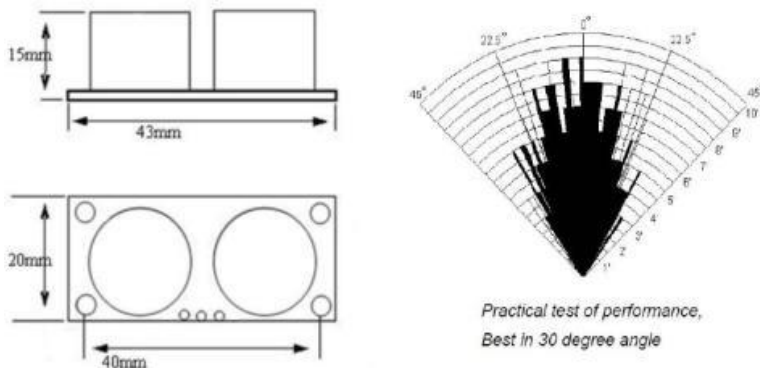

Gambar 7. Jangkauan Sensor Ultrasonik HC-SR04.

Tabel 2. Spesifikasi dan Batasan Sensor Ultrasonik HC-SR04.

\begin{tabular}{|l|c|c|c|c|}
\hline \multicolumn{1}{|c|}{ Parameter } & Min & Typ. & Max & Unit \\
\hline Operating Voltage & 04.50 & 05.00 & 05.05 & $\mathrm{~V}$ \\
\hline Quiescent Current & 01.05 & 2 & 02.05 & $\mathrm{~mA}$ \\
\hline Working Current & 10 & 15 & 20 & $\mathrm{~mA}$ \\
\hline Ultrasonic Frequency & - & 40 & - & $\mathrm{kHz}$ \\
\hline
\end{tabular}

\subsection{Sensor Laju AlirYF-S201}

Sensor aliran adalah alat untuk mengendalikan laju aliran air. Biasanya sensor aliran adalah elemen penginderaan yang digunakan dalam flow meter untuk merekam aliran air.

Untuk lebih jelasnya tampilan fisik dan skematik instalasi sensor laju alir YF-S201 dapat dilihat pada gambar 8 berikut ini:
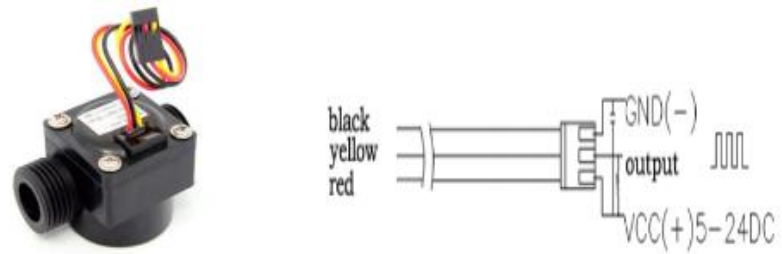

Gambar 8. Sensor Laju Alir YF-S201.

Untuk lebih jelasnya tampilan mekanik dimensi sensor laju alir YF-S201 dapat dilihat pada gambar 9 berikut ini:
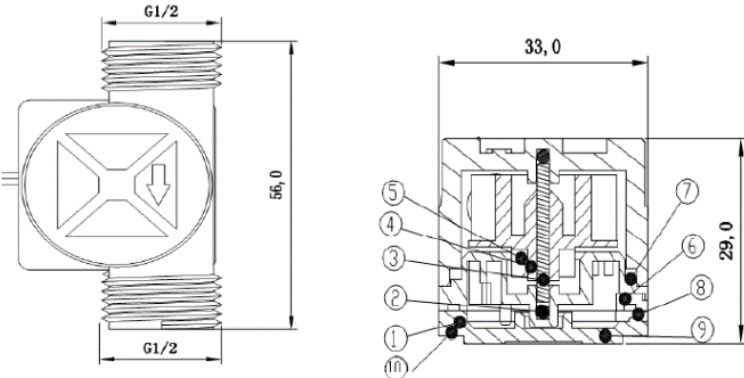

Gambar 9. Mechanic Dimensi Sensor Laju Alir YFS201.

Adapun spesifikasi sensor laju alir YF-S201 adalah sebagai berikut:

1. Debit air yang dapat diukur : 1-30 Ltr/menit

2. Maksimum tekanan air: $2 \mathrm{MPa}$

3. Tekanan hidrostatik / Hydrostatic Pressure : $\leq 1,75 \mathrm{MPa}$

4. Catudaya antara 4,5 Volt hingga 18 Volt DC

5. Arus: $15 \mathrm{~mA}$ (pada $\mathrm{Vcc}=5 \mathrm{~V}$ )

6. Kapasitas beban: $<10 \mathrm{~mA}$ (pada $\mathrm{Vcc}=$ $5 \mathrm{~V})$

7. Rentang kelembabab saat beroperasi: $35 \%-90 \% \mathrm{RH}$ (no frost)

8. Duty Cycle: $50 \% \pm 10 \%$

9. Periode signal (output rise / fall time): $0,04 \mu / 0,18 \mu \mathrm{s}$

10.Diameter penampang sambungan: 0,5 inch $(1,25 \mathrm{~cm})$

11.Amplitude: Low $\leq 0,5 \mathrm{~V}$, High $\geq 4,6$ Volt

12.Kekuatan elektrik (electric strength): 1250 $\mathrm{V} /$ menit

13. Hambatan insulasi: $\geq 100 \mathrm{M} \Omega$

14. Material: PVC

15. Cable Length: $15 \mathrm{~cm}$

16.1/2" Nominal Pipe Connections, 0,78" Outer Diameter, 1/2" of Thread

17. Size: $2,5 "$ x $1,4 "$ x $1,4 "$. [http://www.elecdesignworks.com, 2016]

Fungsi flow meter sistem untuk mengukur gerakan, atau laju aliran dari volume air 
tertentu dan mengekspresikannya melalui sinyal listrik.

\subsection{IC LM2917 (Frequency to Voltage Converter)}

IC LM2917 didesain khusus oleh National Semiconductor sebagai konversi frekuensi ke tegangan (frequency to voltage converter) sehingga tidak membutuhkan komponen eksternal yang banyak. Rangkaian frequency to voltage converter berfungsi sebagai pencacah frekuensi keluaran dari encoder dan mengubahnya menjadi tegangan. Tegangan yang dihasilkan berbanding lurus dengan jumlah frekuansi cacahan. Nilai tegangan ini selanjutnya dijadikan sebagai preset value.

IC LM2917 14-Pin ini memiliki beberapa keunggulan yaitu memiliki dioda zener internal sebagai penyedia tegangan yang stabil, nilai tegangan referensi sinyal $0 \mathrm{~V}$ saat frekuensi $0 \mathrm{~Hz}$.

Pada gambar 10 dapat dilihat rangkaian internal IC LM2917 14-Pin.

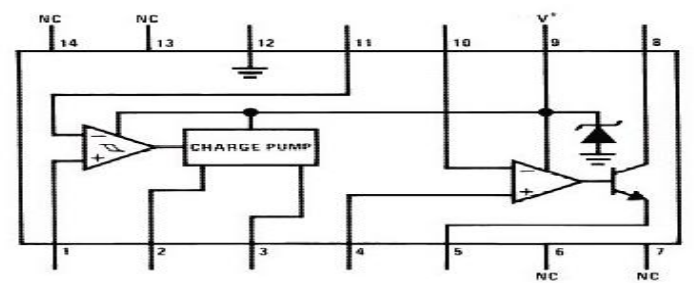

Gambar 10. Rangkaian Internal IC LM2917 14-Pin.

Agar IC LM2917 beroperasi dengan optimal maka harus diperhatikan pemasangan komponen tambahan pada kaki-kakinya, terutama pada empat kaki utama, yaitu:

Kaki 1 : Sinyal masukan

Kaki 2 : C1 ke ground

Kaki 3 : C2 paralel R1 ke ground

Kaki 14 : ground

Pada saat nilai masukan lebih besar atau kecil dari referensi maka charge pump akan aktif. Cara kerja charge pump mirip dengan kapasitor. Semakin tinggi frekuensi sinyal yang masuk, maka proses pengisian muatan menjadi semakin cepat sehingga nilai tegangan DC yang dikeluarkan semakin besar, begitu juga sebaliknya ketika frekuensi semakin kecil maka nilai tegangan DC yang dihasilkan akan semakin kecil pula. Berdasarkan datasheet IC LM2917 besarnya tegangan yang dihasilkan dapat dihitung menggunakan persamaan:

$V_{\text {OUT }}=V_{\text {in }} \times \mathrm{R}_{1} \times \mathrm{C}_{1} \times \mathrm{f}_{\mathrm{n}}$
Keterangan:

$$
\begin{aligned}
& V_{\text {OUT }}=\text { Tegangan keluaran }(\text { Volt }) \\
& V_{\text {in }}=\text { Tegangan in }(\text { Volt) } \\
& \mathrm{R}_{1}=\text { Nilai resistor pada kaki } 3(\Omega) \\
& \mathrm{C}_{1}=\text { Nilai kapasitor pada kaki } 2(\mathrm{~F}) \\
& \mathrm{f}_{\mathrm{n}}=\text { Nilai frekuensi masukan }(\mathrm{Hz})
\end{aligned}
$$

\subsection{Solenoid Valve}

Solenoid valve adalah katup yang digerakkan oleh energi listrik, mempunyai kumparan sebagai penggeraknya yang berfungsi untuk menggerakkan piston yang dapat digerakkan oleh arus DC, solenoid valve atau katup solenoid mempunyai lubang keluaran, lubang masukan dan lubang exhaust.

Cara kerja dari solenoid valve sendiri adalah ketika koil mendapat supply tegangan maka koil tersebut berubah menjadi beban magnet sehingga menggerakkan piston pada bagian dalamnya, ketika piston berpindah posisi maka valve pada elektrik solenoid terbuka.

Pemasangan solenoid valve ini cukup mudah dan menggunakan listrik yang kecil. Solenoid valve adalah kombinasi dari dua dasar unit fungsional, yaitu:

1. Solenoid (elektromagnet) terdiri atas koil yang berfungsi sebagai kumparan,

2. Valve merupakan katup dimana saat solenoid teraliri listrik katup tersebut membuka dan menutup dengan sendirinya. Untuk lebih jelasnya tampilan solenoid valve dapat dilihat pada gambar 11 berikut ini:

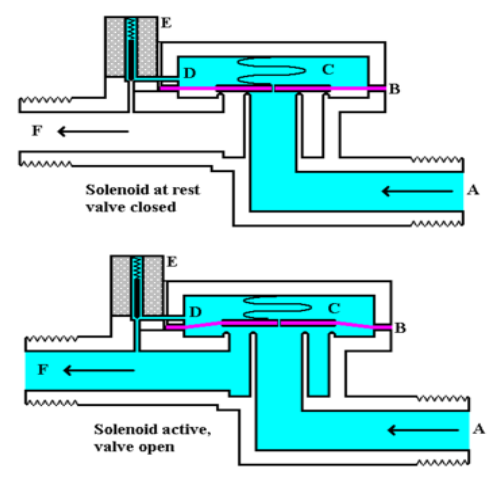

Gambar 11. Solenoid Valve.

Katup solenoid dapat digunakan untuk berbagai macam air dan gas dalam spektrum yang luas dari aplikasi. Penilaian kapasitas katup dalam hal yang berhubungan dengan semua kondisi operasi 
dilakukan dengan menentukan faktor aliran (Cv) dari katup. Nilai faktor aliran (Cv) adalah jumlah galon AS $60^{\circ} \mathrm{F}$ air per menit, ketika mengalir melalui katup, menyebabkan penurunan tekanan dari 1 psi. Ini ukuran kapasitas dinyatakan untuk setiap model.

Ada 5 parameter utama yang harus dipertimbangkan ketika memilih katup: Cv, kompatibilitas media, tekanan, suhu, dan proses fitting. Untuk masing-masing parameter ini, nilai-nilai maksimum yang terdaftar untuk setiap katup. Untuk memilih katup yang benar, membandingkan setiap parameter dan memeriksa bahwa itu adalah kurang dari nilai maksimum yang terdaftar. Untuk sebagian besar aplikasi, air dianggap mampat dan hanya faktor-faktor berikut perlu dipertimbangkan dalam ukuran katup. Faktor-faktor ini mengaitkan sesuatu seperti yang ditunjukkan dalam persamaan berikut:

$C_{V}=Q \sqrt{\frac{G}{\Delta P}}$

Dimana:

$$
\begin{aligned}
& \mathrm{C}_{v}=\text { Flow factor of valve } \\
& \mathrm{Q}=\text { Flow expressed in US gallons per } \\
& \text { minute }(\mathrm{GPM}) \\
& \Delta \mathrm{P}=\text { Pressure drop across the valve = } \\
& \mathrm{P}_{1}-\mathrm{P}_{2} \\
& \mathrm{P}_{1}=\text { Inlet pressure (psig) } \\
& \mathrm{P}_{2}=\text { Outlet pressure (psig) } \\
& \mathrm{G}=\text { Specific gravity of the fluida }(\mathrm{G}= \\
& \left.1,0 \text { forwaterat } 60^{\circ} \mathrm{F}\right) .
\end{aligned}
$$

\subsection{Mikrokontroler Arduino Uno R3}

Mikrokontroler adalah sebuah sistem komputer fungsional dalam sebuah chip. Di dalamnya terkandung sebuah inti prosesor, memori (sejumlah kecil RAM, memoriprogram, atau keduanya), dan perlengkapan input output. Dengan kata lain, mikrokontroler adalah suatu alat elektronika digital yang mempunyai masukan dan keluaran serta kendali program yang bisa ditulis dan dihapus dengan teknik khusus, teknik kerja mikrokontroler sebenarnya membaca dan menulis data.
Arduino adalah kit elektronik atau papan rangkaian elektronik open source yang di dalamnya terdapat komponen utama yaitu sebuah chip dengan jenis AVR dari perusahaan Atmel.

Pada gambar 12 berikut ini diperlihatkan contoh diagram blok sederhana dari ATmega328 yang dipakai pada Arduino Uno.

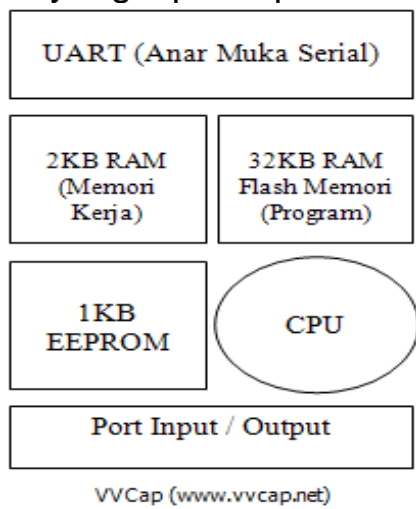

Gambar 12. Diagram Blok Arduino.

Blok-blok diagram dijelaskan sebagai berikut:

1. Universal

Asynchronus

Reseiver/Transmitter (UART) adalah antar muka yang digunakan yang digunakan untuk komunikasi serial seperti pada RS-232, RS-442 dan RS485.</p>

2. $2 \mathrm{~KB}$ RAM pada memori kerja bersifat volatile (hilang saat daya dimatikan), digunakan oleh variabel-variabel di dalam program.

3. 32KB RAM flash memori bersifat nonvolatile, digunakan untuk menyimpan program yang dimuat dari komputer. Selain program, flash memori juga menyimpan boot loader. Boot loader adalah program inisiasi yang ukurannya kecil, dijalankan oleh CPU saat daya dihidupkan. Setelah boot loader selesai dijalankan, berikutnya program didalam RAM akan dieksekusi.

4. 1KB EEPROM bersifat non-volatile, digunakan untuk meyimpan data yang tidak boleh hilang saat daya dimatikan. Tidak digunakan pada papan Arduino. 
5. Central Processing Unit (CPU), bagian dari untuk menjalankan setiap instruksi dari program.

Port Input dan Output, pin-pin untuk menerima data (input) digital atau analog, dan mengeluarkan data (output) digital atau analog.

Setelah mengenal bagian-bagian utama dari ATmega328 sebagai komponen utama, selanjutnya menjelaskan tentang bagianbagian dari papan Arduino itu sendiri.

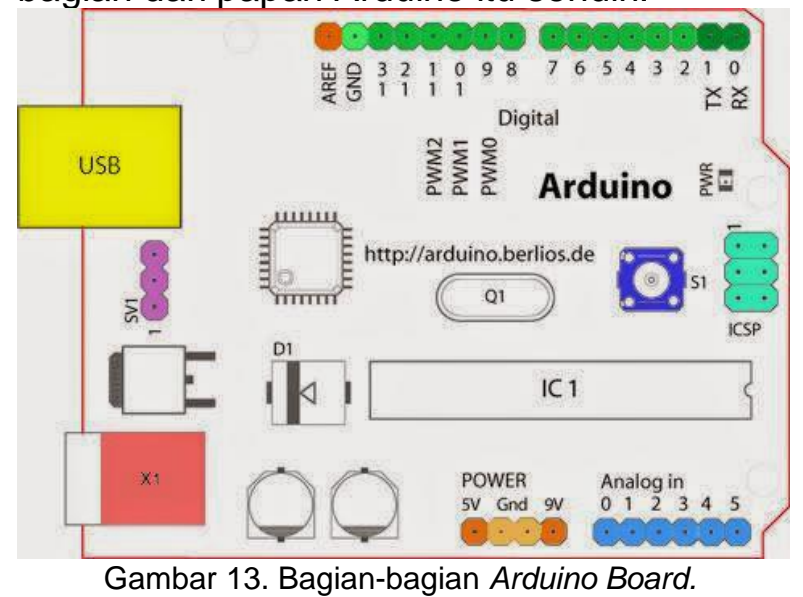

Bagian-bagian komponen dari Arduino Board dapat dijelaskan sebagai berikut:

1. 14 pin input/output digital (0-13)

Berfungsi sebagai input atau output, dapat diatur oleh program. Khusus untuk 6 buah pin 3, 5, 6, 9, 10 dan 11, dapat juga berfungsi sebagai pin analog output dimana tegangan output-nya dapat diatur. Nilai sebuah pin output analog dapat diprogram antara $0-255$, dimana hal itu mewakili nilai tegangan $0-5 \mathrm{~V}$.

2. USB

Berfungsi untuk:

- Memuat program dari komputer ke dalam papan.

- Komunikasi serial antara papan dan komputer.

- Memberi daya listrik kepada papan.

3. Sambungan SV1

Sambungan atau jumper untuk memilih sumber daya papan, apakah dari sumber eksternal atau menggunakan USB. Sambungan ini tidak diperlukan lagi pada papan Arduino versi terakhir karena pemilihan sumber daya eksternal atau USB dilakukan secara otomatis.

4. Q1 - Kristal (quartz crystalo scillator)

Jika mikrontroler dianggap sebagai sebuah otak, maka kristal adalah jantung-nya karena komponen ini menghasilkan detak-detak yang dikirim kepada mikrokontroller agar melakukan sebuah operasi untuk setiap detak-nya. Kristal ini dipilih yang berdetak 16 juta kali per detik $(16 \mathrm{MHz})$.

5. Tombol Reset S1

Untuk me-reset sehingga program akan mulai lagi dari awal. Perhatikan bahwa tombol reset ini bukan untuk menghapus program atau mengosongkan.

6. In-Circuit Serial Programming (ICSP)

Port ICSP memungkinkan pengguna untuk memprogram secara langsung, tanpa melalui boot loader. Umumnya pengguna Arduino tidak melakukan ini sehingga ICSP tidak terlalu dipakai walaupun disediakan.

7. IC 1 - Atmega

Komponen utama dari papan Arduino, di dalamnya terdapat CPU, ROM dan RAM.

8. X1 - sumber daya eksternal

Jika hendak disuplai dengan sumber daya eksternal, papan Arduino dapat diberikan tegangan DC antara 9-12V.

9. 6 pin input analog (0-5)

Pin ini sangat berguna untuk membaca tegangan yang dihasilkan oleh sensor analog, seperti sensor suhu. Program dapat membaca nilai sebuah pin input antara $0-1023$, dimana hal itu mewakili nilai tegangan $0-5 \mathrm{~V}$.

\subsection{Perangkat Lunak LabVIEW}

Menurut Wikipedia, LabVIEW merupakan software yang khusus digunakan untuk pemrosesan dan visualisasi data dalam bidang akuisisi data, kendali dan instrumentasi, serta otomatisasi industri. Software ini pertama kali dikembangkan oleh perusahaan National Instruments (NI) pada tahun 1986, LabVIEW merupakan singkatan dari Laboratory Virtual Instrument Engineering Workbench. Pada 
pemrograman LabVIEW terdiri atas dua jendela yaitu:jendela front panel dan jendela block diagram.

\section{Jendela Front Panel}

Front Panel merupakan bagian dimana pengguna berinteraksi dengan VI ketika program dijalankan. Selain itu pada front panel terdapat bagian kontrol danin dicator. Kontrol berfungsi mengatur parameter dan input yang diinginkan sedang kanin dikator berfungsi sebagai output yang mempunyai tampilan baik itu data, grafik maupun gambar. Untuk mengontrol front panel digunakan mouse dan keyboard untuk memasukkan data yang diinginkan oleh pengguna. [Dian Artanto, 2012]. Front Panel digunakan untuk berinteraksi dengan pengguna pada saat program itu berjalan. Pengguna dapat mengontrol program, mengubah input, dan memantau data secara real-time. Kontrol digunakan untuk pengaturan input, seperti:

1. Setting nilai alarm,

2. Menekan switch on/off,

3. Men-stop program.

Untuk lebih jelasnya tampilan front panel dapat dilihat pada gambar 14 berikut:

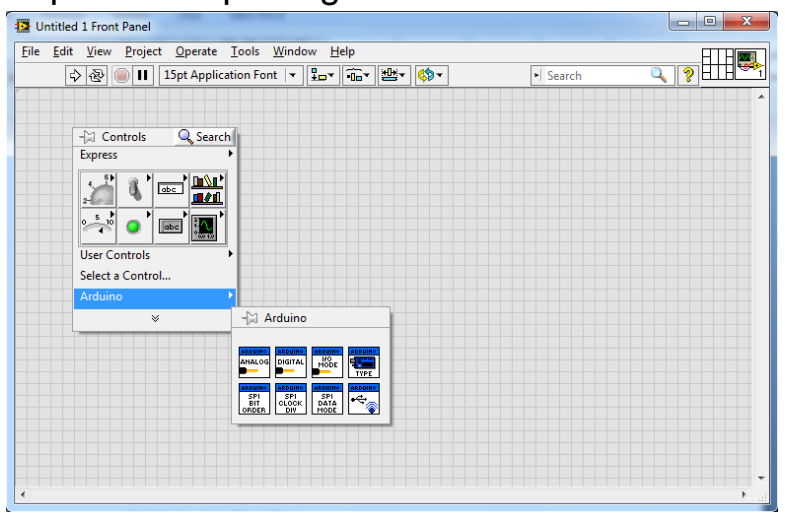

Gambar 14. Tampilan pada Front Panel.

\section{Jendela Block Diagram}

Block diagram merupakan bagian dimana pengguna menghubungkan komponen sehingga program dapat berjalan. Pada bagian ini pengguna juga dapat melihat aliran program berjalan. Block diagram berisiko sumber yang bersifat grafis. Di dalam block diagram objek dari front panel berbentuk terminal, sehingga terdapat:

1. Terminal yang berasal dari front panel,

2. Fungsi dan struktur built-in dari pustak $\mathrm{VI}$,

3. Wire yang menghubungkan semua node Untuk lebih jelasnya tampilan jendela block diagram dapat dilihat pada gambar 15 berikut ini:

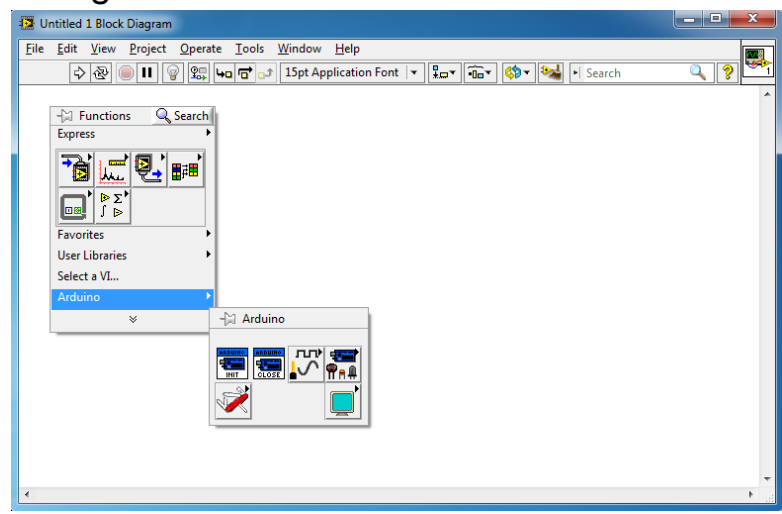

Gambar 15. Tampilan pada Block Diagram.

\section{METODOLOGI}

\subsection{Gambaran Sistem}

Pada penelitian ini menggunakan metode eksperimen. Gambaran sederhana dari sistem yang terlihat pada gambar 16 menunjukkan bahwa pompa air pada tandon terintegrasi sensor ultrasonik terhubung pipa melalui sensor aliran (flow sensor) sebelum melalui titik percabangan, pada percabangan pertama pipa terhubung dengan tangki 1 melalui kontrol inlet valve (IV1) terintegrasi level sensor (LS1) untuk mengalirakan air ke tangki 1, pada percabangan kedua pipa terhubung dengan tangki 2 melalui kontrol inlet valve (IV2) terintegrasi level sensor (LS2) untuk mengalirakan air ke tangki 2, dan pada percabangan ketiga pipa terhubung kembali dengan tandon melalui kontrol drain valve (DV) terintegrasi sensor aliran (flow sensor) untuk mengalirakan air kembali ke tandon. 


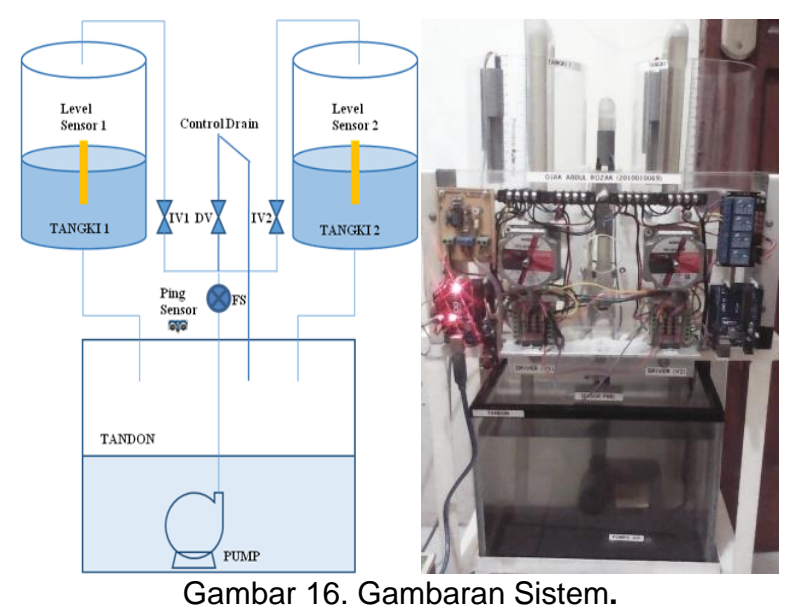

Gambar 17 menunjukkan alur proses (flowchart) dari sistem yang akan dibuat dalam penelitian ini.

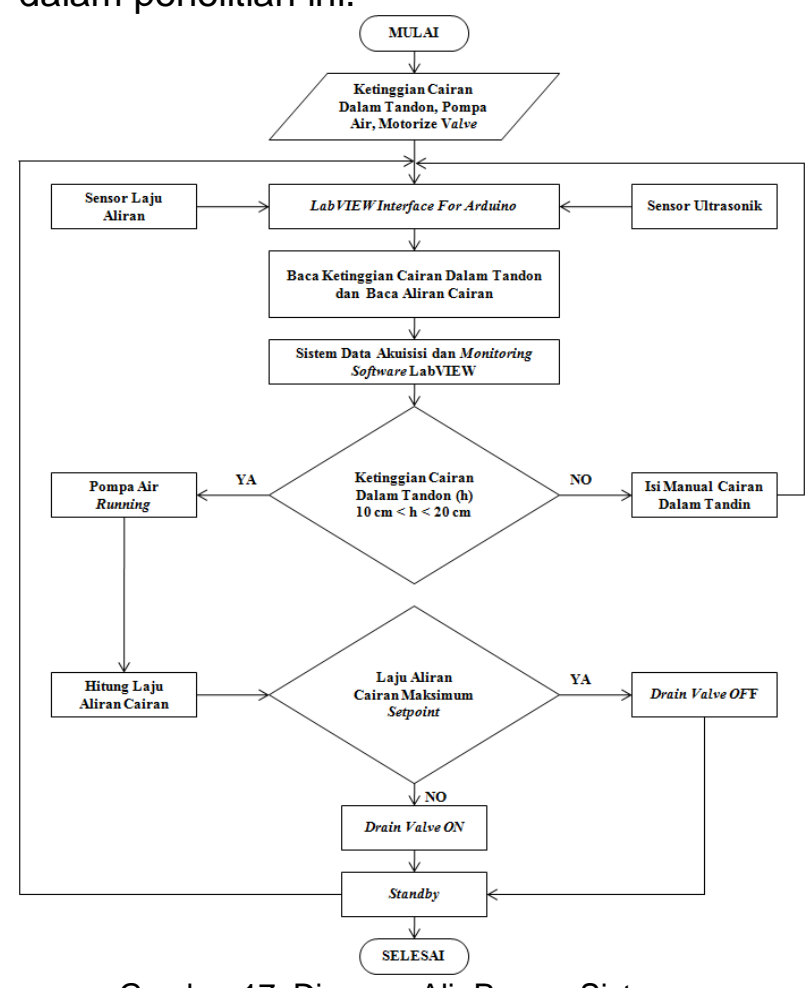

Gambar 17. Diagram Alir Proses Sistem.

\subsection{Perancangan Sistem}

Rancang bangun sistem kendali laju alir fluida pada penelitian ini meliputi perancangan perangkat keras (hardware) dan perancangan perangkat lunak (software), gambar 18 menunjukan block diagram kontrol loop dan gambar 19 menunjukkan block diagram perangkat keras (hardware) dan perangkat lunak (software) dari perancangan sistem tersebut.

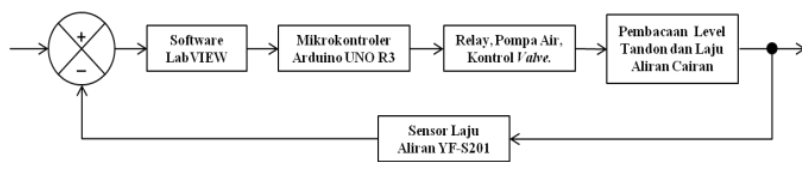

Gambar 18. Block Diagram Kontrol Loop.

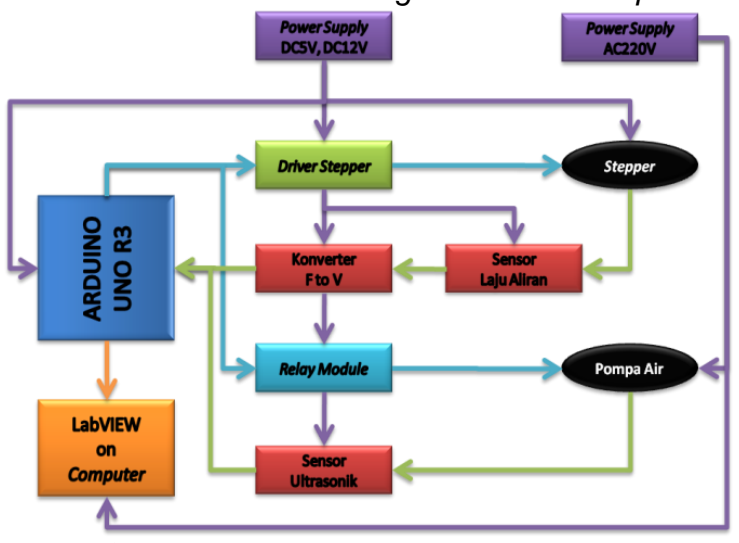

Gambar 19. Block Diagram Perangkat.

\subsection{Perancangan Perangkat Keras (Hardware)}

Perancangan perangkat keras (hardware) merupakan perangkat elektronika sebagai komponen sistem yang menjadi suatu kesatuan sistem dan tidak dapat terpisahkan satu sama lain dari sistem yang dibangun dalam penelitian ini.

\subsection{Perancangan Perangkat Lunak}

Dalam perancangan perangkat lunak pada penelitian ini meliputi pemrograman Arduino Uno R3 yang difungsikan sebagai interface, dan pemrograman LabVIEW sebagai sistem akuisisi data dan monitoring.

\subsection{Pengujian Sistem}

Melakukan pengujian apakah program dapat mendeteksi proses dari sensor, kemudian dapat divisualisasikan pada komputer dengan nilai presisi, akurat dan linier.

\subsection{Analisa dan Kesimpulan}

Hasil dari pengujian sistem dianalisa dan menyimpulkan hasil dari analisis tersebut.

\subsection{Relevansi}

Manfaat dari sistem kontrol berbasis mikrokontroler terintegrasi visualisasi LabVIEW memudahkan dalam pengendalian, perawatan dan trouble shooting pada mesinmesin industri dan bermanfaat bagi mahasiswa Universitas Pamulang khususnya fakultas teknik elektro dalam pembelajaran dan praktikum mikrokontroler dan visualisasi dalam komputer. 


\section{HASIL DAN PEMBAHASAN}

\subsection{Pengujian}

Tujuan pengujian dimaksudkan untuk mengetahui keseluruhan pengujian dari perencanaan yang telah dibuat, dengan demikian akan diketahui tingkat keberhasilan hardware dan software yang telah dibuat dalam tugas akhir ini. Pengujian dilakukan secara perbagian dan kemudian dilakukan pengujian sistem secara keseluruhan. Agar lebih memudahkan pengujiannya dan dibahas masing-masing bagian, pengujian yang dilakukan meliputi:

1. Pengujian drain system,

2. Pengujian operation control reservoir 1 ,

3. Pengujian operation control reservoir 1 ,

4. Pengujian operation control reservoir 1 dan 2

\subsection{Drain system}

Pengujian program LabVIEW drain system bertujuan untuk menguji water flow sensor dengan sistem operasi secara otomatis menghidupkan pompa air dan solenoid valve drain beroperasi sehingga air bersirkulasi hanya pada tendon secara terusmenerus tanpa melalui reservoir.

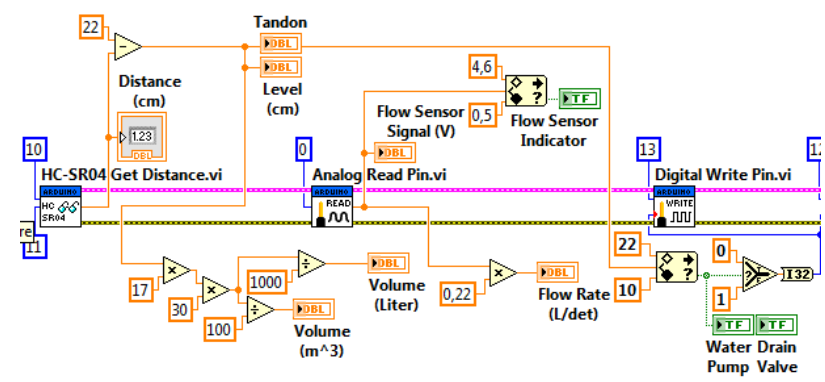

Gambar 20. Tampilan Block Diagram Program Drain System.

Gambar 20 merupakan tampilan dari seluruh nilai akuisisi data dan parameter yang dihasilkan dari sensor ultrasonik HCSR04 dan sensor water flow YF-S201. Saat analog Pin 0 Arduino mendapat signal tegangan VDC dari konverter frekuensi tegangan sebagai keluaran dari sensor alir maka tegangan ini dikali dengan 0,22 untuk mendapatkan nilai flow rate.
Adapun hasil pengujian program LabVIEW drain system dapat dilihat pada tabel 3, Gambar 21 dan gambar 22 berikut: Tabel 3. Hasil Pengujian Program LabVIEW Drain system.

\begin{tabular}{|c|c|c|c|c|c|c|}
\hline Date & Time & $\begin{array}{c}\text { Distance } \\
(\mathrm{cm})\end{array}$ & $\begin{array}{c}\begin{array}{c}\text { Lerel Air } \\
(\mathrm{cm})\end{array} \\
\end{array}$ & $\begin{array}{l}\begin{array}{l}\text { Volume } \\
\text { (Liter) }\end{array} \\
\end{array}$ & $\begin{array}{c}\text { Flow Sensor } \\
\text { Signal (V) }\end{array}$ & $\begin{array}{c}\begin{array}{c}\text { Flow Rate } \\
\text { (L/det) }\end{array} \\
\end{array}$ \\
\hline $05 / 04 / 16$ & $21: 07: 31$ & 2,24 & 19,76 & 10,08 & 3,23 & 0,71 \\
\hline $05 / 04 / 16$ & 21:07:31 & 2,34 & 19,66 & 10,02 & 2,85 & 0,63 \\
\hline $05 / 04 / 16$ & 21:07:31 & 2,34 & 19,66 & 10,02 & 3,23 & 0,71 \\
\hline $05 / 04 / 16$ & 21:07:31 & 2,36 & 19,64 & 10,02 & 3,23 & 0,71 \\
\hline $05 / 04 / 16$ & 21:07:31 & 2,36 & 19,64 & 10,02 & 2,86 & 0,63 \\
\hline $05 / 04 / 16$ & 21:07:31 & 2,24 & 19,76 & 10,08 & 2,84 & 0,62 \\
\hline $05 / 04 / 16$ & 21:07:31 & 2,24 & 19,76 & 10,08 & 3,23 & 0,71 \\
\hline $05 / 04 / 16$ & 21:07:31 & 2,34 & 19,66 & 10,02 & 3,23 & 0,71 \\
\hline $05 / 04 / 16$ & 21:07:31 & 2,36 & 19,64 & 10,02 & 3,23 & 0,71 \\
\hline $05 / 04 / 16$ & $21: 07: 31$ & 2,81 & 19,19 & 9,79 & 2,83 & 0,62 \\
\hline $05 / 04 / 16$ & 21:07:31 & 2,29 & 19,71 & 10,05 & 2,83 & 0,62 \\
\hline $05 / 04 / 16$ & 21:07:31 & 2,79 & 19,21 & 9,80 & 3,23 & 0,71 \\
\hline $05 / 04 / 16$ & $21: 07: 32$ & 2,34 & 19,66 & 10,02 & 2,84 & 0,63 \\
\hline $05 / 04 / 16$ & $21: 07: 32$ & 2,34 & 19,66 & 10,02 & 3,23 & 0,71 \\
\hline $05 / 04 / 16$ & $21: 07: 32$ & 2,34 & 19,66 & 10,02 & 2,85 & 0,63 \\
\hline $05 / 04 / 16$ & 21:07:32 & 2,36 & 19,64 & 10,02 & 3,23 & 0,71 \\
\hline $05 / 04 / 16$ & 21:07:32 & 2,36 & 19,64 & 10,02 & 2,86 & 0,63 \\
\hline $05 / 04 / 16$ & 21:07:32 & 2,36 & 19,64 & 10,02 & 3,23 & 0,71 \\
\hline $05 / 04 / 16$ & 21:07:32 & 2,81 & 19,19 & 9,79 & 2,85 & 0,63 \\
\hline $05 / 04 / 16$ & 21:07:32 & & 19,69 & 10,04 & 2,85 & 0,63 \\
\hline \multicolumn{5}{|c|}{ Rata-rata } & 3,04 & 0,67 \\
\hline
\end{tabular}

Flow Sensor Signal (V)

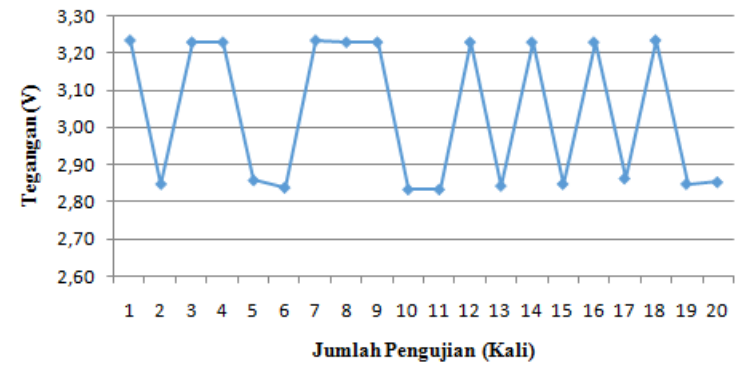

Gambar 21. Grafik Hasil Pengukuran Flow Sensor Signal (V) Drain system.

Flow Rate (L/det)

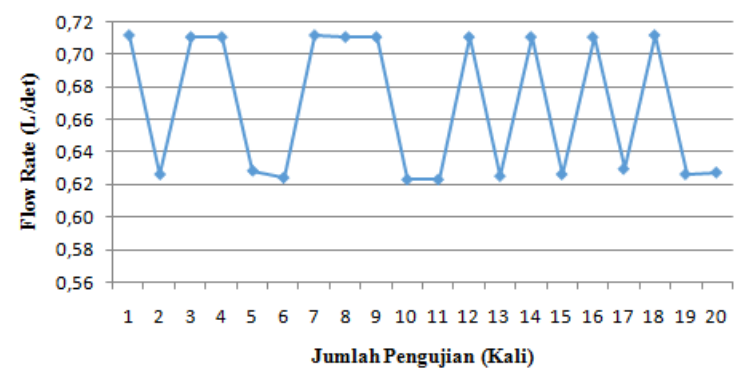

Gambar 22. Grafik Hasil Pengukuran Flow Rate (L/det) Drain system.

Dari tabel dan gambar menunjukkan kestabilan pembacaan dengan rata-rata tegangan $(3.04 \mathrm{~V})$ dan flow rate $(0.67 \mathrm{~L} / \mathrm{det})$ sehingga pembacaan program LabVIEW drain system terimplementasikan untuk mengukur laju alir air.

\subsection{Operation Control}


Pengujian program LabVIEW operation control bertujuan untuk menguji water flow sensor dengan sistem operasi secara otomatis menghidupkan pompa air dan manual kontrol valve 1 untuk mengalirkan air dari tandon ke reservoir 1 dan kontrol valve 2 untuk mengalirakan air dari tandon ke reservoir 2 kemudian membaca flow rate pada saat pengisian masing-masing reservoir tersebut.

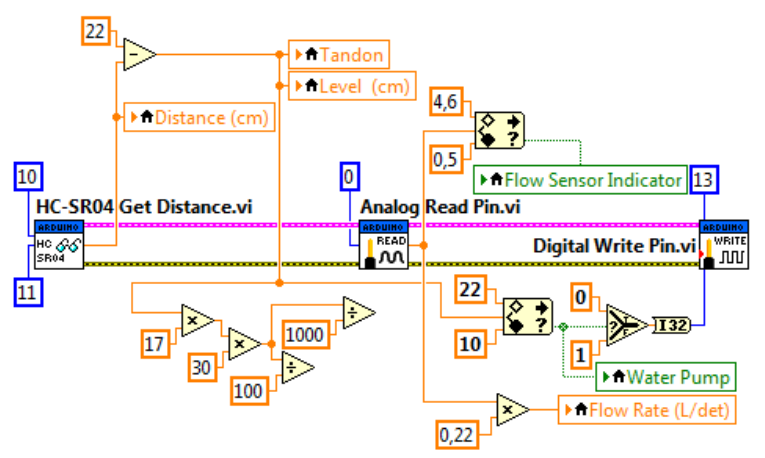

Gambar 23. Tampilan Block Diagram Program Operation Control.

Gambar 23 merupakan tampilan dari seluruh nilai akuisisi data dan parameter yang dihasilkan dari sensor ultrasonik HCSR04 dan sensor water flow YF-S201. Saat analog Pin 0 Arduino mendapat signal tegangan VDC dari konverter frekuensi tegangan sebagai keluaran dari sensor alir maka tegangan ini dikali dengan 0,22 untuk mendapatkan nilai flow rate .

Adapun hasil pengujian program LabVIEW operation contro/ terdapat 3 bagian antara lain:

\section{a. Operation Reservoir 1}

Hasil Pengujian dapat LabVIEW operation reservoir 1 dilihat pada tabel 4 dan gambar gambar 24

Tabel 4. Hasil Pengujian Program LabVIEW Operation Reservoir 1.

\begin{tabular}{|c|c|c|c|c|c|c|}
\hline Date & Time & $\begin{array}{c}\text { Distance } \\
(\mathbf{c m})\end{array}$ & $\begin{array}{c}\text { Lerel Air } \\
(\mathbf{c m})\end{array}$ & $\begin{array}{c}\text { Volume } \\
(\mathbf{L i t e r})\end{array}$ & $\begin{array}{c}\text { Flow Sensor } \\
\text { Signal }(\mathbf{V})\end{array}$ & $\begin{array}{c}\text { Flow Rate } \\
\text { (L/det) }\end{array}$ \\
\hline $05 / 04 / 16$ & $21: 10: 20$ & 3,07 & 18,93 & 9,65 & 2,70 & 0,59 \\
\hline $05 / 04 / 16$ & $21: 10: 20$ & 3,03 & 18,97 & 9,67 & 2,73 & 0,60 \\
\hline $05 / 04 / 16$ & $21: 10: 21$ & 2,88 & 19,12 & 9,75 & 3,11 & 0,68 \\
\hline $05 / 04 / 16$ & $21: 10: 21$ & 2,91 & 19,09 & 9,73 & 2,70 & 0,60 \\
\hline $05 / 04 / 16$ & $21: 10: 21$ & 3,00 & 19,00 & 9,69 & 3,15 & 0,69 \\
\hline $05 / 04 / 16$ & $21: 10: 22$ & 3,00 & 19,00 & 9,69 & 3,14 & 0,69 \\
\hline $05 / 04 / 16$ & $21: 10: 22$ & 3,02 & 18,98 & 9,68 & 2,70 & 0,59 \\
\hline $05 / 04 / 16$ & $21: 10: 22$ & 2,97 & 19,03 & 9,71 & 3,15 & 0,69 \\
\hline $05 / 04 / 16$ & $21: 10: 23$ & 3,00 & 19,00 & 9,69 & 3,14 & 0,69 \\
\hline $05 / 04 / 16$ & $21: 10: 23$ & 2,86 & 19,14 & 9,76 & 2,71 & 0,60 \\
\hline $05 / 04 / 16$ & $21: 10: 23$ & 2,95 & 19,05 & 9,72 & 3,15 & 0,69 \\
\hline $05 / 04 / 16$ & $21: 10: 24$ & 2,97 & 19,03 & 9,71 & 2,69 & 0,59 \\
\hline $05 / 04 / 16$ & $21: 10: 24$ & 2,95 & 19,05 & 9,72 & 3,13 & 0,69 \\
\hline $05 / 04 / 16$ & $21: 10: 24$ & 2,95 & 19,05 & 9,72 & 2,88 & 0,63 \\
\hline $05 / 04 / 16$ & $21: 10: 25$ & 3,02 & 18,98 & 9,68 & 3,09 & 0,68 \\
\hline $05 / 04 / 16$ & $21: 10: 25$ & 3,36 & 18,64 & 9,51 & 3,11 & 0,68 \\
\hline $05 / 04 / 16$ & $21: 10: 26$ & 3,00 & 19,00 & 9,69 & 3,11 & 0,68 \\
\hline $05 / 04 / 16$ & $21: 10: 26$ & 2,95 & 19,05 & 9,72 & 2,71 & 0,60 \\
\hline $05 / 04 / 16$ & $21: 10: 26$ & 3,40 & 18,60 & 9,49 & 3,12 & 0,69 \\
\hline $05 / 04 / 16$ & $21: 10: 27$ & 2,86 & 19,14 & 9,76 & 2,71 & 0,60 \\
\hline & \multicolumn{3}{|l}{ Rata-rata } & & $\mathbf{2 , 9 5}$ & $\mathbf{0}, 65$ \\
\hline
\end{tabular}

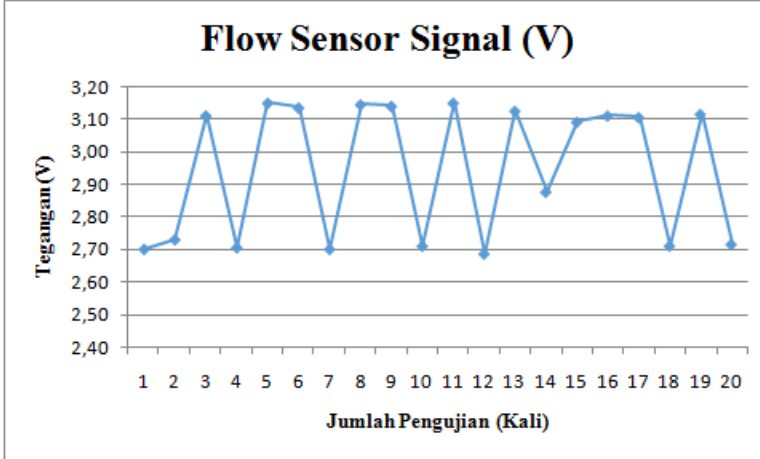

(a)

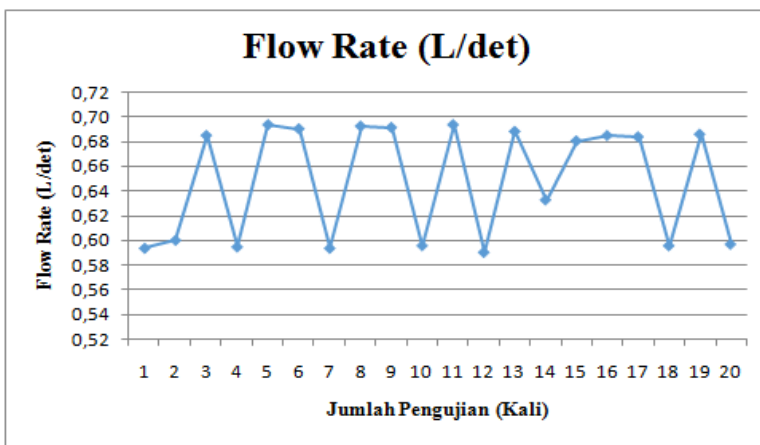

(b)

Grafik 24. (a) Hasil Pengukuran Flow Sensor Signal (V) Operation (b) Grafik Hasil Pengukuran Flow Rate (L/det) Operation Reservoir 1.

Dari tabel dan gambar menunjukkan kestabilan pembacaan dengan rata-rata tegangan $(2.95 \mathrm{~V})$ dan flow rate $(0.65 \mathrm{~L} / \mathrm{det})$, walaupun ada sedikit penurunan dengan hasil pengujian drain system yaitu: tegangan (3.04V) dan flow rate $(0.67 \mathrm{~L} / \mathrm{det})$ akan tetapi mengenai hal ini tidak menjadi masalah karena adanya perbedaan media dan jarak aliran air antara drain system dan operation control, hanya saja yang perlu ditekankan adalah semakin besar tegangan maka 
semakin cepat laju alir airnya, jika tegangan mengecil maka melambat pula laju alir airnya, berarti pengukuran ini sudah sesuai dengan tujuan penelitian pada tugas akhir ini.

\section{b. Operation Reservoir 2}

Hasil Pengujian dapat LabVIEW operation reservoir 2 dilihat pada tabel 5 dan gambar 25

Tabel 5. Hasil Pengujian Program LabVIEW Operation Reservoir 2.

\begin{tabular}{|c|c|c|c|c|c|c|}
\hline Date & Time & $\begin{array}{c}\text { Distance } \\
(\mathrm{cm})\end{array}$ & $\begin{array}{c}\begin{array}{c}\text { Lerel Air } \\
(\mathrm{cm})\end{array} \\
\end{array}$ & $\begin{array}{c}\text { Volume } \\
\text { (Liter) }\end{array}$ & $\begin{array}{c}\text { Flow Sensor } \\
\text { Signal (V) }\end{array}$ & $\begin{array}{c}\text { Flow Rate } \\
\text { (L/det) }\end{array}$ \\
\hline $05 / 04 / 16$ & 21:19:09 & 4,26 & 17,74 & 9,05 & 2,70 & 0,59 \\
\hline $05 / 04 / 16$ & 21:19:10 & 3,86 & 18,14 & 9,25 & 3,13 & 0,69 \\
\hline $05 / 04 / 16$ & $21: 19: 10$ & 3,81 & 18,19 & 9.28 & 2,70 & 0,59 \\
\hline $05 / 04 / 16$ & $21: 19: 10$ & 3,50 & 18,50 & 9,44 & 3,11 & 0,68 \\
\hline $05 / 04 / 16$ & $21: 19: 10$ & 3,74 & 18,26 & 9,31 & 3,12 & 0,69 \\
\hline $05 / 04 / 16$ & 21:19:11 & 3,81 & 18,19 & 9,28 & 3,15 & 0,69 \\
\hline $05 / 04 / 16$ & 21:19:11 & 3,81 & 18,19 & 9,28 & 2,75 & 0,60 \\
\hline $05 / 04 / 16$ & 21:19:11 & 3,76 & 18,24 & 9,30 & 3,15 & 0,69 \\
\hline $05 / 04 / 16$ & 21:19:11 & 3,76 & 18,24 & 9,30 & 3,16 & 0,69 \\
\hline $05 / 04 / 16$ & $21: 19: 12$ & 3,69 & 18,31 & 9,34 & 3,15 & 0,69 \\
\hline $05 / 04 / 16$ & 21:19:12 & 3,24 & 18,76 & 9,57 & 3,13 & 0,69 \\
\hline $05 / 04 / 16$ & $21: 19: 12$ & 3,74 & 18,26 & 9,31 & 2,74 & 0,60 \\
\hline $05 / 04 / 16$ & $21: 19: 12$ & 3,66 & 18,34 & 9,36 & 2,71 & 0,60 \\
\hline $05 / 04 / 16$ & $21: 19: 13$ & 3,66 & 18,34 & 9,36 & 3,16 & 0,69 \\
\hline $05 / 04 / 16$ & 21:19:13 & 3,10 & 18,90 & 9,64 & 3,17 & 0,70 \\
\hline $05 / 04 / 16$ & 21:19:13 & 3,60 & 18,40 & 9,38 & 2,71 & 0,60 \\
\hline $05 / 04 / 16$ & $21: 19: 13$ & 3,60 & 18,40 & 9,38 & 3,13 & 0,69 \\
\hline $05 / 04 / 16$ & 21:19:14 & 3,50 & 18,50 & 9,44 & 2,72 & 0,60 \\
\hline $05 / 04 / 16$ & 21:19:14 & 3,60 & 18,40 & 9,38 & 3,12 & 0,69 \\
\hline $05 / 04 / 16$ & 21:19:14 & 3,45 & 18,55 & 9,46 & 3,12 & 0,69 \\
\hline \multicolumn{5}{|c|}{ Rata-rat } & 2,99 & 0,66 \\
\hline
\end{tabular}

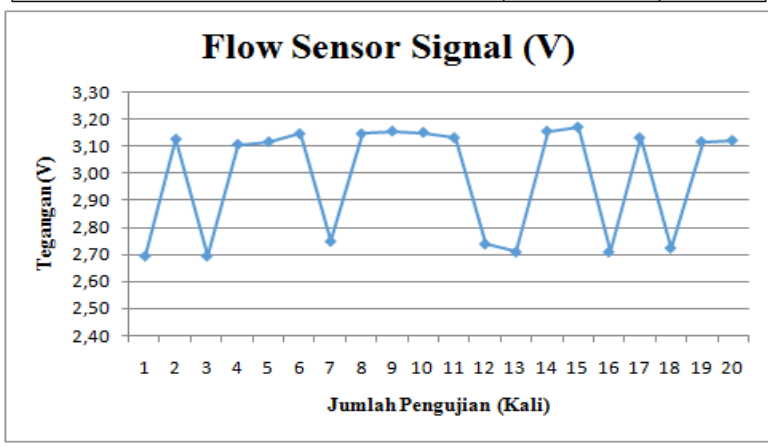

(a)

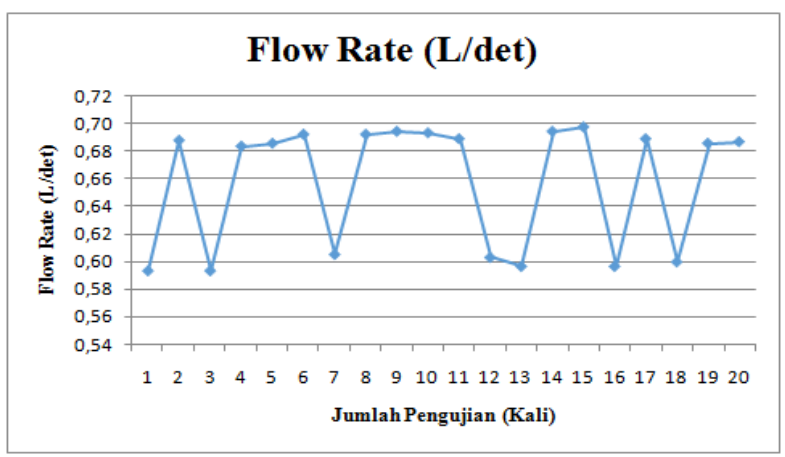

(b)

Grafik 25. (a) Hasil Pengukuran Flow Sensor Signal (V) Operation (b) Grafik Hasil Pengukuran Flow Rate (L/det) Operation

Dari tabel dan gambar menunjukkan kestabilan pembacaan dengan rata-rata tegangan $(2.99 \mathrm{~V})$ dan flow rate $(0.66 \mathrm{~L} / \mathrm{det})$, walaupun ada sedikit penurunan dengan hasil pengujian drain system dan operation reservoir 1 yaitu: operation reservoir 1 dengan rata-rata tegangan $(2.95 \mathrm{~V})$ dan flow rate $(0.65 \mathrm{~L} / \mathrm{det})$ dan drain system dengan rata-rata tegangan $(3.04 \mathrm{~V})$ dan flow rate (0.67 L/det) akan tetapi mengenai hal ini tidak menjadi masalah karena adanya perbedaan media dan jarak aliran air antara drain sistem dan operation control, hanya saja yang perlu ditekankan adalah semakin besar tegangan maka semakin cepat laju alir airnya, jika tegangan mengecil maka melambat pula laju alir airnya, berarti pengukuran ini sudah sesuai dengan tujuan penelitian pada tugas akhir ini.

\section{c. Operation Reservoir 1 dan 2}

Hasil Pengujian dapat LabVIEW operation reservoir 1 dan 2 dilihat pada tabel 6 dan gambar 26

Tabel 6. Hasil Pengujian Program LabVIEW Operation Reservoir 1 dan 2.

\begin{tabular}{|c|c|c|c|c|c|c|}
\hline Date & Time & $\begin{array}{c}\text { Distance } \\
(\mathrm{cm})\end{array}$ & $\begin{array}{c}\text { Lerel Air } \\
(\mathrm{cm})\end{array}$ & $\begin{array}{c}\text { Volume } \\
\text { (Liter) }\end{array}$ & $\begin{array}{c}\text { Flow Sensor } \\
\text { Signal (V) }\end{array}$ & $\begin{array}{c}\text { Flow Rate } \\
\text { (L/det) }\end{array}$ \\
\hline $05 / 04 / 16$ & $21: 21: 37$ & 2,79 & 19,21 & 9,80 & 2,97 & 0,65 \\
\hline $05 / 04 / 16$ & $21: 21: 37$ & 2,86 & 19,14 & 9,76 & 2,97 & 0,65 \\
\hline $05 / 04 / 16$ & $21: 21: 38$ & 3,28 & 18,72 & 9,55 & 2,98 & 0,66 \\
\hline $05 / 04 / 16$ & 21:21:38 & 2,71 & 19,29 & 9,84 & 2,56 & 0,56 \\
\hline $05 / 04 / 16$ & $21: 21: 38$ & 3,29 & 18,71 & 9,54 & 2,58 & 0,57 \\
\hline $05 / 04 / 16$ & 21:21:38 & 2,71 & 19,29 & 9,84 & 2,54 & 0,56 \\
\hline $05 / 04 / 16$ & 21:21:39 & 2,81 & 19,19 & 9,79 & 2,94 & 0,65 \\
\hline $05 / 04 / 16$ & 21:21:39 & 3,31 & 18,69 & 9,53 & 2,95 & 0,65 \\
\hline $05 / 04 / 16$ & $21: 21: 39$ & 3,21 & 18,79 & 9,58 & 2,94 & 0,65 \\
\hline $05 / 04 / 16$ & 21:21:39 & 2,81 & 19,19 & 9,79 & 2,96 & 0,65 \\
\hline $05 / 04 / 16$ & 21:21:39 & 2,81 & 19,19 & 9,79 & 2,59 & 0,57 \\
\hline $05 / 04 / 16$ & 21:21:40 & 3,14 & 18,86 & 9,62 & 2,57 & 0,57 \\
\hline $05 / 04 / 16$ & $21: 21: 40$ & 2,86 & 19,14 & 9,76 & 2,58 & 0,57 \\
\hline $05 / 04 / 16$ & 21:21:40 & 3,31 & 18,69 & 9,53 & 2,56 & 0,56 \\
\hline $05 / 04 / 16$ & 21:21:40 & 3,31 & 18,69 & 9,53 & 2,99 & 0,66 \\
\hline $05 / 04 / 16$ & 21:21:41 & 2,79 & 19,21 & 9,80 & 2,98 & 0,66 \\
\hline $05 / 04 / 16$ & 21:21:41 & 2,67 & 19,33 & 9,86 & 2,55 & 0,56 \\
\hline $05 / 04 / 16$ & $21: 21: 41$ & 3,31 & 18,69 & 9,53 & 2,94 & 0,65 \\
\hline $05 / 04 / 16$ & 21:21:41 & 2,71 & 19,29 & 9,84 & 2,60 & 0,57 \\
\hline $05 / 04 / 16$ & 21:21:42 & 2,79 & 19,21 & 9,80 & 2,57 & 0,57 \\
\hline \multicolumn{5}{|c|}{ Rata-ra } & 2,77 & 0,61 \\
\hline
\end{tabular}

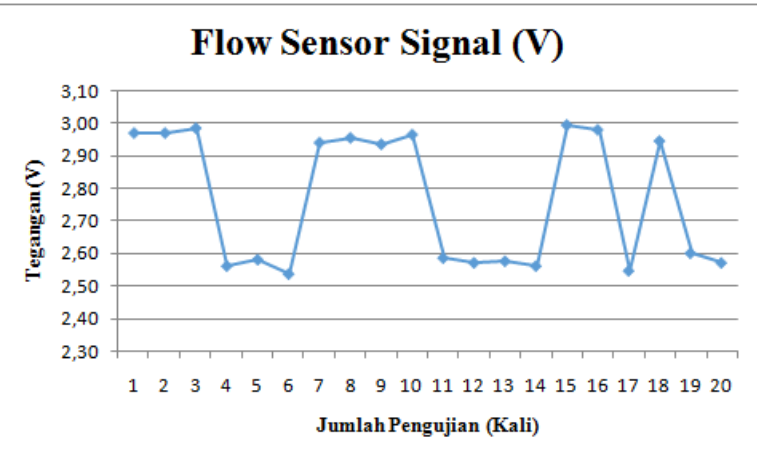

(a) 


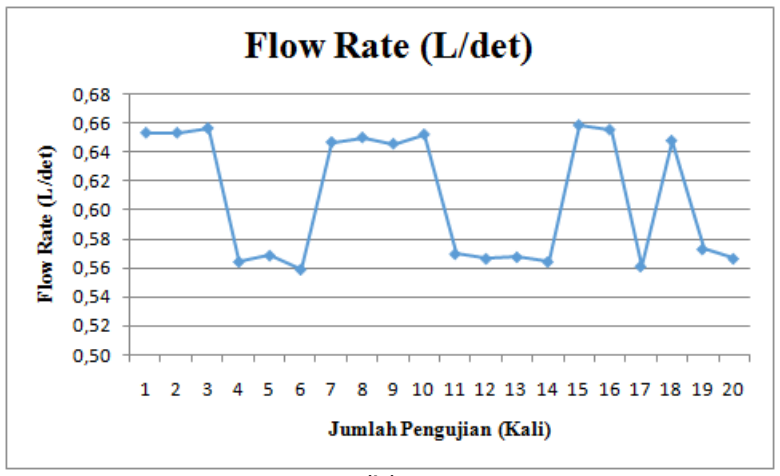

(b)

Grafik 26. (a) Hasil Pengukuran Flow Sensor Signal (V) Operation. (b) Hasil Pengukuran Flow Rate (L/det) Operation

Dari tabel dan gambar menunjukkan kestabilan pembacaan dengan rata-rata tegangan $(2.77 \mathrm{~V})$ dan flow rate $(0.61 \mathrm{~L} / \mathrm{det})$, walaupun ada sedikit penurunan dengan hasil pengujian drain system, operation reservoir 1 dan operation reservoir 2 yaitu: operation reservoir 2 dengan rata-rata tegangan $(2.99 \mathrm{~V})$ dan flow rate $(0.66 \mathrm{~L} / \mathrm{det})$, operation reservoir 1 dengan rata-rata tegangan $(2.95 \mathrm{~V})$ dan flow rate $(0.65 \mathrm{~L} / \mathrm{det})$ dan drain system dengan rata-rata tegangan (3.04V) dan flow rate $(0.67 \mathrm{~L} / \mathrm{det})$ akan tetapi mengenai hal ini tidak menjadi masalah karena adanya perbedaan media dan jarak aliran air antara drain system dan operation control, hanya saja yang perlu ditekankan adalah semakin besar tegangan maka semakin cepat laju alir airnya, jika tegangan mengecil maka melambat pula laju alir airnya, berarti pengukuran ini sudah sesuai dengan tujuan penelitian pada tugas akhir ini.

\section{KESIMPULAN}

1. Sensor ultrasonik HC-SR04 dapat digunakan untuk mengukur level ketinggian dan volume air pada tandon dan mengontrol pompa air secara otomatis dapat terimplementasikan dengan hasil perbandingan antara pembacaan pada LabVIEW dengan ruller hanya terdapat rata-rata error correction $0.08 \mathrm{~cm}$.

2. Sensor water flow YF-S201 dapat digunakan untuk mengukur kecepatan laju alir air (fluida) pada drain system dan operation reservoir
terimplementasikan menunjukkan kestabilan pembacaan dengan rata-rata tegangan $(2,96 \mathrm{~V})$ dan flow rate $(13,40 \mathrm{~L} / \mathrm{det})$ pada drain system, rata-rata tegangan $(2,80 \mathrm{~V})$ dan flow rate $(12,70 \mathrm{~L} / \mathrm{det})$ pada operation reservoir 1 dan rata-rata tegangan $(2,01 \mathrm{~V})$ dan flow rate $(13,66 \mathrm{~L} / \mathrm{det})$ pada operation reservoir 2 .

3. Mikrokontroler Arduino dapat difungsikan sebagai interface dalam sistem komunikasi untuk pembacaan sensor.

\section{DAFTAR PUSTAKA}

[1] Dwi Setyo Pambudi, Yoyok. "Penerapan Pemodelan dan Metode Kurva Reaksi Proses Untuk Mengidentifikasi Sistem Duress". Pusat Teknologi Reaktor dan Keselamatan Nuklir, BATAN. ISSN 0216-3128. 2011.

[2] Rifki Ayub, Nafila. "Rancang Bangun Media Pembelajaran Sistem Kendali Motor". Fakultas Teknik, Universitas Negeri Semarang, Indonesia. 2014.

[3] Suryadharma, Ikhtiari. "Perancangan Kontrol Sistem Distribusi Air Bersih Berbasis Elektro Mekanis". Fakultas Teknik Elektro, Universitas Indonesia, Depok. 2008.

[4] Cryton Technologies. "Sensor Ultrasonik HC-SR04". Product User's Manual V.10. May 2010.

[5] Kusumo A, Radityo. "Studi Konsumsi Energi Listrik Motor Induksi Satu Fasa Penggerak Pompa Air pada Pengisian Tandon secara Bertingkat". Jurusan Elektro Fakultas Teknik, Universitas Diponegoro, Semarang. 2010.

[6] Artanto, Dian. "Interaksi Arduino dan LabVIEW". Jakarta: PT Elex Media Komputindo. Kelompok Gramedia. Anggota IKAPI. 2012.

[7] Munzilin, Rifan. "Rancang Bangun Peralatan Pengaman Pada Toko Perhiasan Berbasis Arduino". Jurusan Sistem Komputer, Konsentrasi Komputer Sistem, STMIK Raharja. Tangerang. 2015 
Journal Of Electrical Power, Instrumentation and Control (EPIC)

Teknik Elektro - Universitas Pamulang 